\title{
Caste: A Socio-political Institution in Hindu Society
}

\author{
Bhanubhakta Sharma Kadel
}

\begin{abstract}
Caste has been a form of social stratification characterized by endogamy, hereditary transmission of a lifestyle, which often includes an occupation, ritual status in a hierarchy and customary social interaction and exclusion based on cultural notions of purity and pollution. Hierarchy, commensality, repulsion and hereditary membership and specialization are the major characteristics of caste system. It is assumed that castes arose from differences in family ritual practices, racial distinctions, and occupational differentiation and specialization but it is socio-political institution mainly characterized by domination and subjugation. APA model has been applied to this research work. The theory of origin of caste and its orientation has been of great use in preparing the article. The readers will be aware of the implicit intention of the writer that the caste system that pervades the South Asian region is not the product of religio-cultural institution nor it has any relation with the Brahminical scripture like the Vedas but it has socio-political orientation.
\end{abstract}

Key Words: caste, cultural, ritualistic, social, economic, political, hierarchy

\section{Introduction}

In general, as Encyclopedia Britannica defines, caste is an endogamous hereditary group of families, bearing a common name; often claiming a common descent; as a rule professing to follow the same hereditary calling; clinging to the same customs, especially regarding purity, meals, and marriages; and often further divided into smaller endogamous circles. Caste is a group of people having a specific social rank, defined generally by descent, marriage, commensality and occupation. Although the term 'caste' is applied to hierarchically ranked groups of people in many different societies around the world, the caste system in its most developed form is found in Indian subcontinent.

The English word "caste" derives from the Spanish and Portuguese casta, which means, "race, lineage, or breed" (Mookherjee, 2012: 56). When the Spanish colonized the New World, they used the word to mean a "clan or lineage." However, the Portuguese were the ones who employed casta in the primary modern sense when they applied it to the many in-marrying hereditary Hindu social groups they encountered upon their arrival in India in 1498.

One of the problems with any understanding of caste is that the word "caste" itself has been used to translate two quite different Sanskrit concepts which are assumed, quite wrongly, to have an automatic connection. One is the concept of $j \bar{t} t i$ and its sense of "kind" or "species". Another way of glossing this concept might be to say "the group that one was born into", the relativity of this gloss conveying the contextual nature of $j \bar{a} t i$ ascriptions. When asked to name their $j \bar{a} t i$, people may name their patrilineage, the name of the group of lineages they conventionally marry into, or even the name of what would now be called an ethnic group. However, even though the concept is elastic, the idea of origin by birth is constant. There is no mystery about this ( Quigley, 1993: 502).

Scholars approaching caste through the study of Hinduism and comparative religion may be less acquainted with sociological and anthropological studies of caste on the ground and are more likely to be familiar with the Vedic concept of varna which is also used to translate the word "caste". The referent of this concept is rather different from that of $j \bar{a} t i$ since the fundamental idea is less "belonging to a group 
by virtue of common birth" than "functions which must be performed if cosmic harmony and social harmony are to prevail" - it being understood that cosmic harmony and social harmony are dependent on each other. What the varna and $j$ a $t i$ concepts share is an idea of "keeping apart" and it is this which allows them to become conflated in the concept of caste.

Thus, the term caste has no universally accepted definition. To some, the term traditionally corresponds to endogamous varnas of the ancient Indian scripts, and its meaning corresponds in the sense of estates of feudal Japan or Europe. To others, endogamous jātis - rather than varnas - are castes. To others such as Risley, castes in India means endogamous groups that resulted from interactions between what once were different races (Risley, 1903: 52). Endogamy, the common element in these three definitions, is itself disputed. According to him, Caste may be dependent on one's occupation (functional) or based on origin or by birth (hereditary). Ambedkar, who was born in India in a social strata considered untouchable, disagreed that the term caste in India can be defined as endogamous groups of India. According to Ambedkar, India during and before the British colonial rule, was a strictly exogamous society because marriage within blood-relatives and class-relations was culturally forbidden. The term caste, according to Ambedkar, should be defined as a social group that tries to impose endogamy, in an exogamous population (1993: 32).

Method: This research paper has been prepard on the basis of secondary data and it is a library based study. Certainly, therefore, no field work has been carried out but books, journals, magazines and electronic materials have been consulted as far as they are availabile and appropriate.

\section{Discussion and Result \\ Varna System}

In traditional Brāhminical law books and much popular usage, Indian society is divided into four social classes, or varnas (Sanskrit for colour or class). At the top of hierarchy are the Brāhmanas (priests or scholors) followed in the rank order by Kshatriyas (warriors or rulers), the Vaisyas (merchants, traders and farmers) and the Shudras (artisans, laborers, servants and slaves). The members of each class are considered to be ritually polluted to varying degrees as a result of defilements brought about by their birth, occupations, dietary habits and customs. Later on with the evolution of society in different stages with different transformation and alteration, the varna system came to be popularly known as caste system but with several modifications.

The famous verse from Rgveda $\mathrm{x}, 90$ speaks of four varnas: brähmana, rājanya (later conventionally referred to as the kshatriya), vaisya, and sudra, each of which springs from a different part of the body of purusa - the lord of beings - who is portrayed as having been sacrificed at the beginning of time. In the ancient Hindu law book known as the Code of Manu (ca. 200 bce to ce 200) varna is portrayed as having a quintessentially different function. These functions revolve around sacrifice: just as the world and the four varnas were created through an initial sacrifice, repetitions of this primal act are necessary if order and harmony are to be maintained. To achieve this, each varna has a specific function:

Manu lays down that the duty of the brähmana is to study and to teach, to sacrifice, and to give and receive gifts; the ksatriya must protect the people, sacrifice and study; the vaisya also sacrifices and studies, but his chief function is to breed cattle, to till the earth, to pursue trade and to lend money; the sudra's duty is only to serve the three higher classes ... for each man there was a place in society and a function to fulfill, with its own duties and rights. (Basham, 1971: 139) There is no mention of any idea that a person performing any specific function must be born into a particular group, though. 
Mahatma Gandhi claimed that Varnāshrama of the shāstras is today nonexistent in practice. The present caste system is theory antithesis of varnāshrama. Caste in its current form, claimed Gandhi, had nothing to do with religion. The discrimination and trauma of castes, argued he, was the result of custom, the origin of which is unknown. Gandhi said that the customs' origin was a moot point, because one could spiritually sense that these customs were wrong, and that any caste system is harmful to the spiritual wellbeing of man and economic well-being of a nation.

\section{Caste as a Religious Product}

In the Indian case, argues Dumont, the idea of caste expresses itself with reference to two ideological features: the opposition of the pure and the impure, and what on the relationship between caste and he calls the "disjunction between status and power (cited as in Quigley, 1993: 497). By the latter he means that those who are the most politically powerful defer to the representatives of religious values because the ultimate meaning of the society derives from those values. This is why, he claims, in everyday life the priest ranks higher than the king, and in the varna schema of the Vedic texts the Brāhmana ranks higher than the Kshatriya. This theory has had pervasive and enduring appeal in spite of a torrent of criticism from every conceivable angle. The reason for this appeal is simple.

One might object, however, that if it is the actual performance of ritual functions which is hazardous for one's status, it is curious that the status of other members of the caste is also compromised even when they do not themselves perform impure tasks. These people are affected because they either come from one's own lineage (i.e. they are related consanguineally), or they come from other lineages with whom members of one's own lineage conventionally marry (i.e. they are related affinally). Caste status cannot therefore be simply "interactional" as Marriott argues (1968: 68) which contrasted with the "attributional" theory of Dumont. Kinship and marriage are also primary determinants of caste status. Ethnographic reports often fail to make clear that all members of castes do not need to perform the ritual function from which they derive their status.

\section{Caste as Occupational Creation}

What is crucial is that one or more members of the caste in question provide the necessary ritual functionary. Caste is often reported to be a matter of occupation. This is false: what is at issue is a periodic ritual contribution to the community. All of the members of one caste may be agricultural labourers yet only some among them may be required to perform a particular ritual function - say, to play music on the occasion of worshipping a particular deity. Another caste (i.e. a group with whom the former will not intermarry) may also be agricultural laborers and have a different ritual function - say, to be pall-bearers for noble castes. Discrimination of this kind can be endless - as with totemic groups (Strauss, 1966: 54). Even among groups where the link between caste and occupation appears more clear-cut, it is rarely the case that all members of the caste perform the job in question. Thus, to be a Barber is not to be a haircutter, but to be related to others whose ritual function involves the cutting of hair and other related tasks, such as nail-paring and midwifery, as elements of purificatory ceremonies. A Barber could, therefore, be a taxi-driver, while the man cutting hair in the barber's shop (i.e. as a profession rather than as part of a ritual function) could well be a member of a Brāhman caste. Similarly, a Brāhman need not be a priest, a Farmer may be a rickshaw driver, and so on.

\section{Caste as a Cultural Institution}

What exactly do we mean by caste? What almost everyone can agree on is that wherever there is caste, certain features are found linked together in a systematic fashion. Perhaps most noticeable, 
particularly to Western eyes, is an apparently constant preoccupation with maintaining differences between groups and expressing these differences through concepts of pollution and inauspiciousness. These groups are based on lineal kinship, and tightly regulated by marriage alliances between households of different lineages. From one perspective, regulating marriage often appears to be a device on the part of wealthy households for inhibiting the dispersal of land ownership. But non-landowning lineages, whether wealthy merchants or impoverished groups, also regulate their marriages just as strictly as members of landowning lineages (Flood, 2003: 543). The fundamental message being circulated by members of all "castes" (i.e. groups of intermarrying lineages) is invariably phrased in terms of an encouragement to prevent one's own "kind" from being contaminated, with the word for "kind" in most Indian languages being jāti (or some variant thereof), a concept which might also be translated as "species". It is as if members of different groups were saying: "We are different from each other in the same way that different animal species are. Just as cats and dogs cannot interbreed, neither can we" (Flood, 545). Since some relativist thinkers are reluctant to say that people with other cultural ideas are "wrong," it needs perhaps to be stressed (if we are going to explain the ideology that different castes must not miscegenate) that there is, in fact, only one human species and its members are not prevented from interbreeding because of their different origins. The arbitrary, cultural nature of the prohibition on intermixing is shown more clearly still by the fact that it is not restricted to procreation. Members of different castes are generally convinced that they should not eat together and that they should abstain from performing certain rituals together.

It is not uncommon for a village to have multiple castes all claiming to abjure relations of any fundamental kind with each other. But why should there be such a proliferation of "kinds" wherever there is caste? A preliminary clue is that in caste-organized communities normally one kind predominates in every sense-politically, economically, numerically, and as the provider of the main patrons of rituals. Conventionally referred to as the "dominant" caste, they are more accurately entitled with the term "noble" or "kingly" caste, it being understood that nobility and kingship are refractions of each other (Srinivas, 1959: 125). All of the other castes are groups of lineages which have an obligation to provide people who perform specialized ritual duties for the noble caste. To default on these obligations always incurs some kind of sanction, which is frequently underpinned by the threat, if not the actual use of, violence.

While there is a great deal of variation among theorists regarding the alleged underlying mechanisms which generate this phenomenon whereby a multiplicity of groups all fastidiously distinguish themselves from each other, most people would agree that certain features stand out when caste is compared to other forms of social organization (Quigley, 1993: 496). Of these perhaps the most striking is the institution of untouchability whereby members of certain castes are so excluded that they appear on occasion to be beyond the pale of normal society. One very common, and perfectly acceptable, way to approach caste is thus by explaining untouchability. Most impure are the untouchables, or, to use modern names, the exterior or scheduled castes, which, however, have among themselves numerous divisions, each of which regards itself as superior to others.

Hocart brings together these principles of organization in caste society by arguing that castes are "families" which hereditarily transfer ritual functions in order to ensure that the king and nobles remain in a pure state (1950: 20). In contrast to the idea that caste is oriented to a pure-impure axis with Brāhmans and Untouchables at polar ends he argues that what is at stake is the integrity of kinship, the institution to which everyone is connected. By implication, it is a very fragile integrity which can only be maintained by the repeated performance of rituals (sacrifices).

\section{Caste as Social Hierarchy}


Dumont says that to adopt a value is to introduce hierarchy, and a certain consensus of values, certain hierarchy of ideas, things and people, which is indispensable to social life (cited as in Dirks, 2004: 4). Caste is still the defining feature of social organization in the Indian subcontinent. Views of caste differ markedly; from those who see it as a religious system to those who see it as a merely social or economic, from those who admire the spiritual foundations of a sacredotal hierarchy to those who look from below and see the tyranny of brāhmanas; from those who view it as the Indian equivalent of community to those who see it as the primary impediment to community (Dirks, 2004: 5). Caste, and specifically caste forms of hierarchy, whether valorized or despised- is somehow fundamental to Hindu civilization, culture and tradition.

Dumont attempts to escape from the notion of caste-as-stratification by introducing us to a second meaning of "hierarchy," that of the encompassment of the part by the whole, which implies also the encompassment of something by its contrary (1996: 76). Thus, for example, in traditional societies the individual is encompassed by society and in caste society, argues Dumont, the pure encompasses the impure (76). He argues that Western theorists and those influenced by them tend to see caste through modern, individualistic spectacles and to apply a set of judgments which are not applicable in the "holistic" traditions of caste-organized communities where the individual is subordinated to, encompassed by, the moral claims of the collective (77). He is perfectly correct to state that caste ideology gives primacy to the whole community and has no place for the modern Western concept of individualism where people are free to make their own choices about whom they associate with. In connection with this, everyone will agree with Dumont that caste involves a "heavy" and pervasive use of ritual for structuring social relations which in many other societies are structured by centralized political and economic institutions.

Hocart's approach endorses Dumont's assertion that the separation of king and priest (as he put it, the "disjunction between status and power") is central to the theory of caste (Quigley, 1993:511). But Quigley says that Dumont was quite wrong about the dynamic of relations between kings and priests and the underlying structure they depended on. Nobility and kingship are not a simple matter of material dominance, but are concerned with the ability to command rituals which bring the community together and expurgate the inauspiciousness which social life habitually generates. Priests are the instruments who perform this purging function and who therefore make possible kingship and nobility. Caste organization could thus be said to be a division of the community into noble and kingly families on the one hand and priests on the other, provided it is understood that the primary function of priests is to cleanse the society of anything which threatens it with death and evil. "In theory, power is ultimately subordinate to priesthood, whereas in fact priesthood submits to power (Dumont, 1966:71-2)."

It is a curious fact, then, that there is a near-unanimous consensus that caste and Hinduism are inextricably linked that "Caste is the Hindu form of social organization. No man can be a Hindu who is not in caste (Lipner, 1990: 3)." However, Lipner reminds us that there is a dissenting, minority view which states that one must be very careful in making this equation: "The caste system, though closely integrated into the [Hindu] religion, is not essential to it. ... Even the profession of belief in the authority of the Veda is not essential (Brockington, 1981: 4)."

Hindus themselves often claim that Brahmans are the "highest" caste and untouchables the "lowest" and Dumont's approach appears to provide an explanation for this. But this common popular formulation of the order of castes runs into problems immediately. First, there are thousands of Brāhman castes whose members daily dispute each other's status. Evidently, if one Brāhman caste claims superiority over another Brāhman caste, not all of them can be the

"highest." And if some Brahmans are "higher" than others, then the criterion of being "higher" obviously must be by virtue of something other than simply being a Brāhman. But what? This is one of the trickiest, 
and most contested, questions in the explanation of caste (Quigley, 1993: 496).

Caste has now been so much "inscribed in ritual, familial, communal, socio-economic, political and public theater of quotidian life (Dirks, 2004: 6)." He further says: "In fact caste was configured as an encompassing Indian social system in direct relationship to the constitution of Hinduism as a systematic, confessional, all embracing religious identity. It was an ideal system, of mutual responsibility, reasoned interdependence and genuine spiritual authority (10). " That caste was introduced to make the society more organized and make the people responsible to the jobs they were supposed to perform in order that to make society smoother. It, however, has now been a very powerful vehicle of dominance-ritual as well as political and economic and the process of ethnicization, or substantialization, of caste; old caste system was based on interdependency rather than conflict as it has been today (Dirks, 2004: 7). On the other hand, hierarchy, repulsion and hereditary specialization have been the main important characteristics of the caste system.

\section{Caste as a Political Institution}

Indian society, indeed caste itself, was shaped by political struggles and processes (Dirks, 2004: 4-5). Kings were killed, and it cleared the way for the transformation of the caste under colonial rule. Caste was refigured as a distinctly religious system (12). In the West civil societies, liberal phenomena were being introduced; however in India, caste was understood always to have resisted political intrusion; it was already a kind of civil society in which it regulated the private domain, such as it was (Dirks, 13).

Under colonialism caste was made far more pervasive, far more tantalizing and far more uniform than it had ever been before (Dirks, 13). At the same time it was defined as a fundamentally religious social order. In fact, however, caste had always been political- it had been shaped in fundamental ways by political struggles and processes. In pre-colonial India, the units of social identity had been multiple, and their respective relations and trajectories were part of complex, conjectural, constantly changing political world. The referents of social identity were not only heterogeneous; they were also determined by context. Temple communities, territorial groups, lineage segments, family units, royal retinues, warrior sub-castes, "little" kingdoms, occupational reference groups, agricultural or trading associations, devotionally conceived networks and sectarian communities; even priestly cabals were just some of the significant units of identification, all of them at various times for more significant than any uniform metonymy of endogamous caste "groupings" (Dirks, 13). It shows that caste, or rather some of the things that seem most easily to come under the name of caste, was just one category among many others, one way of organizing and representing identity of the people of the time.

The idea of the varna- the classification of castes into four hierarchical orders with the Brāhamans on the top could conceivably organize the social identities and relations of all Hindus across the civilization expanse of the Indian subcontinent was only developed under the particular circumstances of British colonial rule (Dirks, 14) even though hierarchy in the sense of rank or ordered difference might have been a pervasive feature of old Indian society. Caste had been political all along, but under colonialism was anchored to the service of colonial interest in maintaining social order, justifying colonial power, and sustaining a very particular form of indirect rule. Religious symbols, organizations and spectacle convert into political ones (Herzfeld, 2004: 128).

\section{Conclusion}

There were so many revolutions in order to evict caste difference and discrimination from the Hindu social system and there were so many reformative actions and reservations carried out, even in the leadership of the father of Indian nation, Mahatma Gandhi, but caste did not die, it did not fade away, 
and it could no longer be diagnosed as benign. At the same time caste remains the single most powerful category for reminding the nation of the resilience of poverty, oppression, domination, exclusion and the social life of privilege.

Caste is not a basic ancient expression of Hindu tradition but is a modern phenomenon, that it is, specifically, the product of an historical encounter between India and Western colonial rule. Under the British rule "caste" became a single term capable of expressing, organizing and above all systemizing the diverse forms of social identity, community and organization of the Indian sub-continent. It was during 200 years of British domination, colonialism that made caste what it is today throughout the subcontinent. In fact, religious rites have become political rights in Hindu society.

\section{Acknowledgement}

This paper has been prepared with the inspiration and insight of Professor Dr. Shreedhar Prasad Lohani who suggested to work on one of the most controversial but neglected area of Caste system in Hindu society. The writer is thankful to the JRCC team led by Professor Dr. Bikash KC for its publication, as well.

\section{References}

Ambedkar, Bhim R. (1933). "A Note to Gandhi." Harijan 3: 14-25

Basham, A. L. (1971). The Wonder that was India. London: Fontana/Collins.

Brockington, J. L. (1981). The Sacred Thread: Hinduism in its Continuity and Diversity.

Edinburgh: Edinburgh University Press.

Dirks, Nicholas B. (2004). Castes of Mind: Colonialism and the Making of Modern India. Delhi: Permanent Black.

Dumont, Louis. (1966). Homo Hierarchicus: The Caste System and its Implications. Chicago: University of Chicago Press.

Encyclopædia Britannica. (2014). Ultimate Reference Suite. Chicago: Encyclopædia Britannica.

Flood, Gavin, ed. (2003). Blackwell Companion to Hinduism. Oxford: Blackwell Publishing Ltd.

Herzfeld, Michael. (2004). Anthropology: Theoretical Practice in Culture and Society. New Delhi: Rawat

Publication.

Hocart, A. M. (1950). Caste: A Comparative Study. London: Methuen.

Levi-Strauss, Claude. (1966). The Savage Mind. London: Weidenfeld and Nicolson.

Lipner, J. (1994). Hindus: Their Religious Beliefs and Practices. London: Routledge.

Marriott, M. (1968). "Caste Ranking and Food Transactions: A Matrix Analysis.” Structure and Change in Indian Society. Eds. Singer, M and B. S. Cohn. Chicago: Aldine.

Mookherjee, Braja Dulal . (2012). The Essence of Bhagavad Gita. New Delhi: Academic Publishers.

Quigley, Declan. (1993). The Interpretation of Caste. Oxford: Clarendon Press.

Risley, H. H. (1903). Ethnographic Appendices, in GOI, Census of India, 1901 1. Calcutta: Office of the Superintendent of Government Printing. 45-62.

Srinivas, M. N. (1959). “The Dominant Caste in Rampura," American Anthropologist 61:1-16. 